\title{
Effectiveness of Deep Breathing Exercise to Reduce Stress among Senior Citizens in Selected Old Age Home at Chennai
}

\author{
V. Hemavathy ${ }^{1}$, Lincy . $S^{2}$ \\ ${ }^{1}$ Principal, Sree Balaji College of Nursing, Bharat University, Chennai, India \\ ${ }^{2}$ II nd Year M.Sc Nursing, Sree Balaji College of Nursing, Bharat University, Chennai, India
}

\begin{abstract}
Background of the Study: Old age is the whole art of life. Old age consist of ages nearing the life expectancy of human beings and thus the end of the human life cycle. Old age has its own beauties. No young man can have those beauties. Old age is not so full of energy, but things are settling and depth is arising. If you miss your youth, you will miss your old age. Objectives: To assess the pre test and post test level on stress among senior citizen. To determine the effectiveness of deep breathing exercise on the level of reducing stress among senior citizen. To associate the post level of stress with the selected demographic variables among senior citizen. Hypothesis: There is a significant difference between the pre test and post test level of stress among senior citizen Methodology: Non equivalent control group pre-test and post-test design was selected for this study. Purposive sampling technique was used for the study. Final Result and Conclusion: In the pre test the level of stress among selected 30 samples 6(20\%) Of them had mild stress and 10(33.3\%) of them had moderate stress and 14(46.6\%) had severe stress. In the post test level of stress 16(53.3\%) of them had mild stress and 14(46.6\%) had moderate stress. The effectiveness of deep breathing exercise on reduce stress among senior citizens using paired " $t$ " test shows 10.5 significant at the level of $P<0.05$ Which implying that there was significant decrease in the level of stress in the post test.
\end{abstract}

Keywords: stress, effectiveness, deep breathing exercise, senior citizens ,old age home

\section{Introduction}

Deep breathing techniques can relax, and are effective in many things like controlling subconscious mind, using mind to $90 \%$ release stress. First school is home. Grandparents are the first teachers. Grandparents teach customs, culture, norms. They can guide younger generation in needed situation helps to lead a healthier life.TheWHOreport of 2004 states that 236 elderly people per ten thousand populations suffer from mental illness mainly due to stress.

\section{Objectives}

- To assess the pre test and post test level on stress among senior citizen.

- To determine the effectiveness of deep breathing exercise on the level of reducing stress among senior citizen.

- To associate the post level of stress with the selected demographic variables among senior citizen.

\section{Hypothesis}

H1-There is a significant difference between the pre test and post test level of stress among senior citizen.

H2 -The mean post test on stress score will be significantly lesser than the mean post test stress score among senior citizen.

H3-There will be a significant association between the post test stress level of the senior citizen and their selected demographic variables

\section{Methodology}

Non equivalent control group pre-test and post-test design was selected for this study in Kakkumkarangal old age home, Chennai. The study population will comprise of senior citizens in the age group of (50-70) years. Total sample size 30 both male and female senior citizens are selected for the study by Purposive sampling technique. The questionnaire has 2 parts consisting of Demographic variables these are age,gender, , religion, education, previous occupation, income ,marital status, type of family .in the second part of questionnaire perceived stress scale was used .Interpretation of score was done as follow

Table 1

\begin{tabular}{|c|c|}
\hline Category & Score \\
\hline Mild & $0-15$ \\
\hline Moderate & $16-25$ \\
\hline Severe & $26-40$ \\
\hline
\end{tabular}

\section{Result}

Table 2: Pre test level of stress

\begin{tabular}{|c|c|c|}
\hline \multirow{2}{*}{ Pretest Level of stress } & \multicolumn{2}{|c|}{ Pre-Test } \\
\cline { 2 - 3 } & No & Percentage (\%) \\
\hline Mild & 6 & 20 \\
\hline Moderate & 10 & 33.3 \\
\hline severe & 14 & 46.6 \\
\hline Total & 30 & 100 \\
\hline
\end{tabular}

Reveals that among 30 samples $6(20 \%)$ of them had mild level of stress , $10(33.3 \%)$ had moderate level of stress and $14(46.6 \%)$ of them had severe level of stress in the pre test. 


\section{International Journal of Science and Research (IJSR) \\ ISSN (Online): 2319-7064}

Index Copernicus Value (2013): 6.14 | Impact Factor (2014): 5.611

Table 3: post test level of stress among senior citizens.

\begin{tabular}{|c|c|c|}
\hline \multirow{2}{*}{ Posttest Level of stress } & \multicolumn{2}{|c|}{ Post-Test } \\
\cline { 2 - 3 } & No & Percentage (\%) \\
\hline Mild & 16 & 53.3 \\
\hline Moderate & 14 & 46.6 \\
\hline severe & - & - \\
\hline Total & 30 & 100 \\
\hline
\end{tabular}

Table 4: Comparison of pre test and post test Level of stress among senior citizens

\begin{tabular}{|c|c|c|c|c|c|}
\hline \multirow{2}{*}{ Level of stress } & \multicolumn{2}{|r|}{ Pre-Test } & \multicolumn{2}{|r|}{ Post-Test } & \multirow{3}{*}{ Chi-square } \\
\hline & No & Percentage & No & Percentage & \\
\hline Mild stress & 6 & 20 & 16 & 53.3 & \\
\hline Moderate stress & 10 & 33.3 & 14 & 46.6 & $\mathrm{~T}=10.5$ \\
\hline severe stress & 14 & 46.6 & 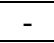 & - & $\mathrm{P}<0.05$ \\
\hline Total & 30 & 100 & 30 & 100 & \\
\hline
\end{tabular}

Reveals the comparison of Deep breathing exercise among stress .It shows that $20 \%$ of them had mild level of stress , 33.3\% had moderate level of stress and $46.6 \%$ of them had severe level of stress in the pre test. $53.3 \%$ were mild, $46.6 \%$ had moderate stress in the post test. the effectiveness of deep breathing exercise among senior citizens the stress mean score was 23.1 in the pre-test, SD was 7.3 and mean post -test score was 16.8 and SD was 3.1 , so the total overall value reduction was 3 and SD was 3.6 with the paired t- test value is 10.5 and there is significant effectiveness at $\mathrm{P}$ value is $2.05<0.05$

\section{Major Findings of the Study}

Regarding the demographic variables in the age group reveals that in $(17 \%)$ of the samples were in the age group of 50-55 years and (23\%) of samples belonged to the age group of 56-60 years and ( $40 \%$ ) of samples to the age group of 61-65 years and (20\%) of samples to the age group of 6670 years. Regarding the gender status (57\%) males and $(43 \%)$ females in the experimental group. In religion status $(50 \%)$ in Hindu $(33 \%)$ christianand $(17 \%)$ in muslim. Regarding education about $(27 \%)$ in illiterate and (33\%) high school, $(20 \%)$ higher secondary, $(20 \%)$ in graduate . Regarding previous occupation about( $43 \%$ ) in un employee, $(17 \%)$ in private job,(13\%) in government job and $(27 \%)$ self employee. Regarding income about (27\%)Below Rs. 5000/- ,(40\%) Rs.6000/-to Rs.10,000/$(17 \%)$ in Rs.11,000/-to Rs.15,000/- and (17\%) in above Rs.16,000/-Regarding marital status about (77\%) in married persons and $(23 \%)$ in un married person. Regarding type of family about $(60 \%)$ in nuclear family and $(40 \%)$ in joint family.

In the pre test the level of stress among selected 30 samples $6(20 \%)$ of them had mild level of stress , 10( $33.3 \%$ ) had moderate level of stress and $14(46.6 \%)$ of them had severe level of stress. In the post test the level of stress among selected 30 samples 16( 53.3\% )were mild , 14( 46.6\%) had moderate stress .

\section{Conclusion}

The study reveals that there was significant decrease in the level of stress among elderly in the post test. The effectiveness of deep breathing exercise reduce the stress among the senior citizens using paired " $t$ " test shows 10.5 significant at the level of $\mathrm{P}<0.05$

\section{References}

[1] K. Consolo, S. Fuoner ,S.Staib Effects of diaphragmatic breathing on stress levels of nursing students, Teaching and learning in nursing, Volume 3 , Issue 2, page 67-71.

[2] Basavanthappa BJ. Nursing Research. $2^{\text {nd }}$ ed. New Delhi: Jaypeebrothers publishers; 2009.

[3] Blazer D. Textbook of Clinical Psychology. $4^{\text {th }}$ ed. New York: American psychiatry publisher; 2003.

[4] Clifford T.Morgan. Introduction to Psychology. $4^{\text {th }}$ ed. New York: Tata McGraw-Hill Publishing Company Ltd; 1993.

[5] Denise F.Polit, Cheryl Tatano, Beck. Nursing Research - Principles and Method. $7^{\text {th }}$ ed. New York: Lippincott William and Wilkins Publication; 2002.

[6] Diahakeable. The Management of stress. $2^{\text {nd }}$ edition. New York: Churchill Livingstone Publication; 1999.

[7] Doris Smith Suddarth. The Lippincott Manual of Nursing Practice. $5^{\text {th }}$ ed. New Delhi: JB Company; 1999

[8] http/www.pubmed.com

[9] http/www.intelihealth.com

[10] http/www.learnwell.og/relax.htm 